\title{
Shade tolerance within the context of the successional process in tropical rain forests
}

Gerardo Avalos ${ }^{1,2}$

1. Escuela de Biología, Universidad de Costa Rica, 11501-2060 San Pedro, San José, Costa Rica; gerardo.avalos@ucr.ac.cr

2. The School for Field Studies, Center for Sustainable Development Studies, 100 Cummings Center, Suite 534-G Beverly, MA 01915-6239 USA; avalos@fieldstudies.org

Received 30-IX-2018. C Corrected 26-II-2019. Accepted 26-III-2019.

\begin{abstract}
Shade tolerance (the capacity to survive and grow over long periods under shade) is a key component of plant fitness and the foundation of current theories of forest succession in tropical rain forests. It serves as a paradigm to understand the optimal allocation of limited resources under dynamic light regimes. I analyze how tropical rain forest succession influences the expression of ecophysiological mechanisms leading to shade tolerance, and identify future areas that will increase our understanding of the ecological and evolutionary consequences of this phenomenon. Shade tolerance is a multivariate, continuous functional trait reflecting the growthmortality trade-off of investing resources under limited light vs. exploiting high light conditions. I propose the life cycle successional trajectory model of Gómez-Pompa \& Vázquez-Yanes as an integrative tool to understand tropical rain forest succession. This model shows how species distribute along the successional environmental gradient based on their degree of shade tolerance and represents a more integrative paradigm to understand the interface between different aspects of species diversity (ontogenetic variation and functional diversity) throughout succession. It proposes that different trait combinations determining shade tolerance are expressed at different stages of the life cycle, which affects how and when plants enter the successional trajectory. Models explaining the expression of shade tolerance (resource availability, carbon gain, CSR, resource competition) are based on whole-plant economics and are not mutually exclusive. The analysis of shade tolerance is biased towards tree seedlings in the understory of mature forests. Other life stages (juvenile and adult trees), life forms, and microhabitats throughout the forest profile are almost always excluded from these analyses. More integrative explanations based on the distribution of functional traits among species, ontogenetic stages, and the nature of the environmental gradient are being developed based on long-term data and chronosequence comparisons. In summary, shade-tolerance is a complex phenomenon, is determined by multiple characters that change ontogenetically over space and time and entails considerable plasticity. Current methods do not account for this plasticity. Understanding the nature of shade tolerance and its functional basis is critical to comprehending plant performance and improving the management, restoration and conservation of tropical rain forests given the combined threats of global warming and habitat loss.
\end{abstract}

Key words: environmental filtering; functional traits; gap phase; leaf-economics spectrum; niche differentiation; ontogenetic niche shifts; plant-economics spectrum; secondary succession; shade tolerance; regeneration niche.

Avalos, G. (2019). Shade tolerance within the context of the successional process in tropical rain forests. Revista de Biología Tropical, 67(2) Suplemento, S53-S77.

One of the fundamental goals of tropical rain forest community ecology is to explain the high level of species diversity and the lack of dominance of a single species. Tropical ecologists have long pursued the question of what determines such high levels of species diversity across different groups (Denslow, 1987; Hubbell, 1997; Givnish, 1999; Wright, 2002) by addressing the historical (Hillebrand, 2004; Mittelbach et al., 2007; Jansson, 
Rodríguez-Castañeda, \& Harding, 2013), physical (i.e., Huston, 1999), and biological components of the latitudinal gradient in alpha and beta diversity (Novotny et al., 2006). There are multiple explanations for the diversity patterns of tropical rain forests (i.e., Wright, 2002), but most fall into two general categories: deterministic and stochastic models. Deterministic models make emphasis on biological or environmental factors predicting species abundance and diversity across space and time, whereas stochastic models assume the influence of random conditions affecting species diversity. Niche divergence and environmental filtering constitute two of the most common deterministic mechanisms explaining the low abundance of most plant taxa (Kraft et al., 2015). In plants, resource partitioning in a narrow portion of the gradient, especially during the early phases of succession, results in niche divergence at different stages of the life cycle (Ackerly, 2003; Poorter \& Arets, 2003; Kraft, Valencia, \& Ackerly, 2008). Niche divergence leads to the differential distribution of plant species throughout their ontogeny into specific environments (environmental filtering), reflecting the adaptive role of functional traits matching organisms with the physical conditions of the successional gradient (Reich et al., 2003; Wright et al., 2010; Sterck, Markesteijn, Schieving, \& Poorter, 2011; Spasojevic, Yablon, Oberle, \& Myers, 2014). Other deterministic explanations stress biological interactions (i.e., predation and plant-herbivore interactions), such the differential mortality hypothesis or Janzen-Connell model (Janzen, 1970). Stochastic models include neutrality theory (Hubbell, 2001), dispersal limitation, and the role of the initial species composition (Weiher et al., 2013) determining species abundance and diversity throughout succession (Webb, Cannon, \& Davies, 2008). Both deterministic and stochastic factors come into play to define a species' regeneration strategy (regeneration niche), integrating physiological trade-offs as well as biotic and abiotic filters (Weiher et al., 2013) into a life history tactic of habitat selection across forest succession, from seeds to adults (sensu Poorter, 2007). Understanding the evolution of the regeneration niche, expressed as ontogenetic changes in functional traits (mediated by biotic interactions such as competition and plant-herbivore relationships), is critical to understanding not only the causes of tropical forest diversity, but the very nature of ecological communities. This knowledge goes beyond an academic discussion and is urgently needed to ensure that conservation, management, and restoration strategies coincide with the regeneration requirements of the plant species involved. This goal is increasingly important considering the multiple threats to tropical diversity (e.g., habitat loss, increased fragmentation, and the fast pace of climate change; see Bradshaw, Sodhi, \& Brook, 2009). These threats are changing the evolutionary rules of slow-growth taxa thriving in resource-limited conditions.

Shade tolerance, traditionally defined as the capacity to survive long periods under deep shade, is a critical component of plant fitness under dense canopies (Valladares \& Niinemets, 2008; Valladares, Laanisto, Niinemets, \& Zavala, 2016). This concept must be expanded to include the capacity to compete and grow in the shade. Shade tolerance is a complex, multifactorial and continuous plant response directly related to life history adaptation. However, our understanding of the extent and consequences of shade tolerance is biased towards instantaneous traits (i.e., photosynthetic rate), which show faster responses to changes in light conditions and are relatively easier to analyze compared to traits that require more time to stabilize (i.e., relative growth rate and allocation patterns). This bias also includes a few -and usually the most abundant- ontogenetic stages and life forms, such as tree seedlings, and a limited range of microhabitats (i.e., the understory of mature rain forests). However, a thorough understanding of shade tolerance and how it varies during the successional process is critical to comprehending plant performance and the evolution of functional traits, and key concepts driving plant and community 
structure and evolution, such as competition and succession (Valladares et al., 2016).

Shade-adapted or shade-tolerant species have a slower growth rate and a more restricted capacity to respond to sudden environmental changes (Strauss-Debenedetti \& Bazzaz, 1996). Since many tropical rain forest plants spend some time in the shade, either as seeds, seedlings or saplings, juveniles, or adults, understanding their adaptation to variable periods of shade during succession is of vital importance to the management of the remaining tracts of tropical rain forests (Melo, Arroyo-Rodríguez, Fahrig, Martínez-Ramos, \& Tabarelli, 2013).

My objective in this review is to analyze the ecological and evolutionary consequences of shade tolerance within the context of tropical rain forest succession. To understand the relevance of shade tolerance, it is necessary to review successional dynamics and the adaptation to successional gradients. This is ultimately linked to theories explaining community structure. This analysis will be restricted to the rain forests sensu lato following the classic criteria of Richards (1952). Following these criteria, tropical rain forests consist of evergreen, hygrophilous, and structurally complex vegetation up to $30 \mathrm{~m}$ in canopy height, and complex in life forms in addition to trees (epiphytes, lianas, palms, understory herbs). Rain forests are concentrated in tropical areas with abundant rainfall, warm temperatures, and weak climatic seasonality. In other types of tropical forests, such as tropical dry forests, light limitation does not determine the idiosyncrasy of the successional process as strongly, compared to factors such as water distribution, temperature, and air humidity (Lebrija-Trejos, Pérez-García, Meave, Poorter, \& Bongers, 2011).

My goal is to focus on the successional process of mature tropical rain forests after a natural disturbance (i.e., tree-fall gaps). Other scenarios where succession is important include disturbed secondary forests, extractive reserves, abandoned agricultural fields, forest fragments, and forest regeneration after considerable disturbances or catastrophes, such as extensive fires and hurricanes. The origin of the disturbance clearly affects the direction of succession, its duration, and the species composition (Arroyo-Rodríguez et al., 2017). It is not my intention to cover all possible scenarios, especially for human-disturbed forests, but to concentrate on mature tropical forests after a natural disturbance. This does not disregard the fact that succession takes place under other conditions; discussing these alternative scenarios is beyond the scope of this review.

\section{THE MECHANISTIC BASIS OF SHADE TOLERANCE}

Shade tolerance is a multivariate, continuous trait: Shade tolerance facilitates survival under deep shade by maintaining the carbon balance and the growth rate close to zero (Kobe \& Coates, 1997). Shade tolerant life stages remain suppressed under low light by keeping a balance between high survivorship and slow growth (the competition-colonization and growth-mortality trade-off). Under shade, the strategy of biomass allocation must target light interception and investment in defenses at different organismal scales, from physiological processes at the cellular level (i.e., activation of phytochromes, instantaneous photosynthetic responses, and regulation of morphological processes) to changes in plant architecture and resource allocation (Valladares \& Niinemets, 2008). However, the concept of shade tolerance must incorporate not only the ability to survive and endure shade but also the capacity to grow and compete under other sources of stress, such as drought or herbivory (Valladares \& Niinemets, 2008). Different degrees of shade tolerance, expressed at various stages in the life cycle, could determine the phase in which a species enters the successional trajectory. Valladares and Niinemets (2008) compiled a list of traits conferring shade tolerance, from cellular and leaf processes to whole plant scales. This list is not exhaustive and being limited to the physiological measurement of shade tolerance at the plant level, it does not include the demographic or ecosystemlevel implications of shade tolerance (but see 
Valladares et al., 2016). Shade tolerance varies from instantaneous, leaf-level responses (i.e., photosynthetic rate and stomatal conductance) to long-term, whole-plant responses such as changes in growth and resource allocation (i.e., relative growth rate, fecundity, longevity, carbon distribution). Since the distinction between shade-tolerant and light-demanding species is rooted in the demographic trade-off of growth vs. mortality, traits that more efficiently integrate plant fitness over longer periods (i.e., biomass production) should have a higher predictive value for shade tolerance than traits expressed over shorter time scales (i.e., photosynthesis rate, stomatal conductance). Hence, it is necessary to extend the analysis of shade tolerance to demographic and ecosystem scales, to facilitate the understanding of the influence of this process on succession dynamics, and ecosystem processes such as nutrient cycling and carbon sequestration.

Over short time scales the degree of shade tolerance is traditionally measured using the parameters of the photosynthetic light response curve, such as light compensation point and respiration rate (Valladares \& Niinemets, 2008). Over longer time scales seedling or sapling survival, leaf lifespan and defense, and biomass partitioning become more important (Poorter, 2009; Kitajima \& Poorter, 2010). More integrative approaches incorporate fitness components at the whole-plant level, such as relative growth rate and the amount of total biomass accumulated as a function of light magnitude (i.e., the whole light compensation point of Baltzer $\&$ Thomas, 2007). All these approaches are consistent with processes favoring survival in the shade, such as the maximization of carbon gain under low light (i.e., achieved by adjusting plant architecture to decrease self-shading, Chazdon, 1986), increase in carbon storage which is eventually spent in pulses to favor growth and reproduction in understory plants during times of increased light, and investment in traits favoring seedling survival in the shade (increased leaf toughness, higher concentration of secondary compounds, and longer leaf lifespan, Poorter, 2009). Of all these traits, seed mass (Kitajima, 1994; Poorter \& Rose, 2005) is the best predictor of shade tolerance since it integrates different selective pressures, such as dispersal mode, impacts of pathogens and herbivores, and the overall capacity to cope with reduced resources. The combination of traits directly related to biomass production (i.e., seed mass, leaf dry mass per unit area, photosynthetic capacity, and whole plant relative growth rate), determines the capacity not only to survive the shade but to grow and reproduce in low light (shade performance).

There are different strategies to withstand the shade. Some plants complete their life cycle under shade (i.e., some understory palms, ferns, and clonal shrubs) whereas other groups can survive extended shade periods but need to reach the canopy to reproduce. Wright et al. (2010) found that wood density explained more than $80 \%$ of the variation in the distribution of species along the growth-mortality trade-off. Wood density is an efficient integrator of ontogenetic changes in plant allocation strategies for most woody plants and is directly related to demographic parameters such as mortality and relative growth rate (Poorter et al. 2008), although it might not as important for palms (Tomlinson, 2006) and lianas (Putz, 1984), which have different growth strategies and tissue properties relative to trees. There is clearly a bias in measuring the responses of short-term characters relative to plant traits that integrate responses over extended periods and are more significant within a specific life stage in the life cycle of tropical species. For instance, Poorter et al. (2008) found leaf traits to be more important influencing the growth/ survival trade-off in seedlings, whereas wood density was more effective in predicting mortality rates in adult trees.

Since multiple environmental factors affect suites of traits that determine growth and survival in the shade, shade tolerance should be analyzed as a multivariate trait or performance trade-off (i.e., the growth-mortality trade-off, Gravel, Canham, Beaudet, \& Messier, 2010) in which increased fitness under shade favors growth and survival under limited light. As a 
result, the plant's capacity to respond to sudden light increases, specifically growth and survival under high light, is restricted (MacArthur \& Levins, 1964; Kitajima, 1994; Wright et al., 2010). The evolution of shade tolerance centers on the growth-survival trade-off; this process maintains high species diversity because it favors niche divergence among species and ontogenetic stages through the partitioning the light resource at very fine scales (Wright, 2002). This concept is critical to predicting changes in community organization and succession, and ultimately, ecosystem function.

The mechanistic basis of shade tolerance constitutes the foundation of classic works in plant ecophysiology (i.e., Chazdon \& Fetcher, 1984); for instance, photosynthetic induction in response to sunflecks (Chazdon \& Pearcy, 1991), and cytochrome-mediated responses affecting plant morphology and gas exchange (i.e., Lee, Baskaran, Mansor, Mohamad, \& Yap, 1996). These responses affect instantaneous carbon fixation and long-term patterns of biomass allocation and architecture. Sunflecks represent transient, intermittent, and intense pulses of high levels of photosynthetically active radiation (PAR) that reach shaded environments without being filtered by the canopy. The light energy received during a sunfleck could be two orders of magnitude higher than the average diffuse light levels of the forest understory. Most sunflecks are extremely brief (60\% of sunflecks lasted less than $30 \mathrm{~s}$ in Chazdon \& Pearcy's 1991 study) and are clustered temporally. However, they account for up to $75-80 \%$ of total daily photon flux density in the shade (Chazdon \& Fetcher, 1984; Chazdon \& Pearcy, 1991). The energy contained in sunflecks is responsible for most of the daily carbon fixed by understory plants. Shadetolerant plants require minutes to hours to be fully induced. Once induction is reached, subsequent sunflecks are utilized more efficiently. At the level of seconds to minutes, plants adjust chloroplast orientation and the concentration of photosynthetic enzymes and electron carriers to benefit from sunflecks (Way \& Pearcy, 2012). The spatial and temporal distribution of sunflecks is responsible for the high variability in the light regime of the forest understory.

Under deep shade, plants maximize carbon gain but minimize respiration costs (Kitajima, 1994). To achieve this, respiration rates are low, congruent with low values of net photosynthesis rate. In addition, slow growth is punctuated by peaks in biomass accumulation when resources are favorable (growth and reproduction take place in pulses and sometimes out of population synchrony, Sylvester \& Avalos, 2013). In shade tolerant plants a low reproductive output is sustained over long periods, and can combine with increased clonal propagation (i.e., the genus Piper; Greig, 1993), increased biomass allocation targeting higher light interception (in the palms Geonoma cuneata and Asterogyne martiana; Chazdon, 1985), high efficiency in leaf area distribution while minimizing leaf overlap and increasing light harvesting efficiency (in the palm Calyptrogyne ghiesbreghtiana; Alvarez-Clare \& Avalos, 2007), and increased allocation to storage roots (i.e. Asterogyne martiana, Alvarez-Vergnani \& Avalos, in prep.) Although there is great variation in seed mass, shade-tolerant species tend to have large seeds, storage cotyledons, low relative growth rate, low specific leaf mass, and low leaf area ratio (Kitajima, 2002).

The list of functional traits associated with shade tolerance discussed by Valladares \& Niinemets (2008) leads to a relative general shade-adapted syndrome, reflecting the covariant nature of many traits that determine survival under low light. Valladares and Niinemets (2008) also showed that, although the shade tolerance syndrome is consistent across species, it can vary following ontogenetic changes in growth and mortality across size classes within changing environmental conditions and differences in growth forms (Dalling et al., 2001, Niinemets, 2006; Santiago \& Wright, 2007; Wright et al., 2010). The final shade-adapted phenotype, and thus the nature of the shade response, depends on the covariation of multiple morphological and physiological traits as plants move across different ontogenetic stages and light environments. The list of Valladares 
and Niinemets (2008) overlooked some key traits, such as delayed greening (Prado, Sierra, Windsor, \& Bede, 2014). Delayed greening is the production of new leaves that are red or light green, tender, and have variable levels of secondary compound defenses. Leaf greening takes place once the leaf is fully expanded, and mechanical defenses replace chemical defenses (Kursar \& Coley, 1992). This strategy is frequent in shade-adapted, understory species, which can sustain heavy herbivore damage during leaf expansion, but since the lost leaf area lacks nitrogen and photosynthetic compounds, the strategy is relatively cost-efficient (Clark \& Clark, 1991).

In summary, shade tolerance has a genetic basis (Gommers, Visser, St Onge, Voesenek, \& Pierik, 2013), is subject to natural selection, is context-dependent, can be understood as a shade-adapted syndrome, and varies across space and time. The final response to shade will depend on the combination of other stress factors such as drought (Markesteijn, Poorter, Bongers, Paz, \& Sack, 2011), nutrient deficiencies (Niinemets, 2010a), herbivore damage (Boege \& Marquis, 2005), and competition (Wright, 2002).

\section{UNDERSTANDING SHADE TOLERANCE}

Since shade tolerance is a multivariate trait, an integrative approach considering life history trade-offs and multiple morphological and physiological traits (or functional trait spectra, following Lohbeck et al., 2015) is mandatory. Different theories serve to explain the evolutionary development of these tradeoffs (Diaz et al., 2004). These theories form the foundation of classic models of plant evolution, resource allocation, and forest succession, serve to organize the complexity of shade tolerance, and help to comprehend overall plant performance and growth strategies within a given context of resource availability (i.e., Tilman, 1994; Pacala \& Rees, 1998). Any model aiming to explain plant growth in response to changing resources can be used to explain differences in shade adaptation and are inherently economic since they implement a cost-benefit analysis (i.e., the survival-adaptation trade-off) to explain how plants allocate limited resources to adapt to changing environments (Diaz et al., 2004; Reich, 2014; Lohbeck et al., 2015). The sun-shade dichotomy has been the classic subject for explaining species differences in forest succession, light acclimation, photosynthetic performance, and evolution of life-history trade-offs, but as discussed above, it is an oversimplification of the shade tolerance continuum. These models are not mutually exclusive but revolve around the concept of changing resource availability and the time necessary to express adaptation. In other words, a plant will adapt to shade depending on the frequency in which it experiences light limitation throughout its life cycle (i.e., the opportunity for adapting to low resources depends on the frequency in which a species experiences a limited environment during its life cycle). The frequency of exposure to shade determines the magnitude of plasticity, measured as different phenotypes expressed over a physical gradient over time, as reflected in the trajectory of the reaction norm. The time in the ontogenetic trajectory where the observation is made is critical in determining the categorization of high vs. low plasticity, assuming that responses have stabilized in the new environment. Some species require more time to adapt to a sudden change in light, which does not necessarily indicate less plasticity relative to a species expressing adaptation more quickly (Valladares, Sánchez-Gómez, \& Zavala, 2006).

In the following paragraphs, I review four of the most common conceptual models relevant to understand plant adaptation to limited conditions, one of them being shaded environments.

\section{Resource availability hypothesis or opti-} mal defense: This model represents the most general explanation for resource allocation under variable environmental conditions. Originally proposed to explain differences in the quality and quantity of defenses against herbivores (i.e., Coley, Bryant, \& Chapin, 1985; 
Bazzaz, Chiariello, Coley, \& Pitelka, 1987), the model serves as a suitable framework to describe differences in growth related to shade tolerance. It is compatible with more general hypotheses based on the economics of tradeoffs in resource allocation (i.e., optimal allocation theory and allometric biomass partition theory, see McCarthy \& Enquist, 2007; or the "worldwide leaf economics spectrum", Wright et al., 2004). The model proposes that the level of resources available -and the type of resource limiting plant growth-determines the kind and amount of defenses. The quality of defenses and their metabolic cost is a function of the amount of resources available to maintain existing defenses and generate new ones. For instance, if resources are in short supply, plants will invest in permanent, nitrogen-based, quantitative defenses that have high initial costs but that are more efficient since they require less maintenance and synthesis (in other words, are more cost-effective). In contrast, if resources are abundant, plants will invest more in mobile, qualitative defenses that have low initial costs but require continuous synthesis and maintenance (i.e., alkaloids, cardiac glycosides). The level of investment in defenses varies with resource quality, the intensity of herbivory (defenses can be induced; Schaller, 2008), and plant ontogeny (Boege \& Marquis, 2005).

Similar principles apply to shade tolerance. If resources are scarce (i.e., limited light), plants will invest in long leaf lifespans, more efficient crown architectures with less leaf overlap, and a decreased relative growth rate. Plants also grow in pulses (will accumulate resources under shade and will spend those resources in growth and reproduction when light conditions improve). The relative importance of this allocation strategy, and thus, of the intensity of shade tolerance, varies with ontogeny. By increasing in size, plants move into a different light environment while changing simultaneously their allocation relationships (i.e., investment in reproductive structures could be more important than increased light interception). In summary, if light is limited, plants will express the shade-adaptive syndrome, which is analogous to the mechanism controlling the generation of defensive compounds.

The work of Kitajima (1994) on Barro Colorado Island, Panama, was one of the first to analyze in detail the optimality trade-off under limited resource conditions. Kitajima (1994) found that seedling survival in the shade was related to morphological traits increasing defense against herbivores and pathogens (high leaf construction costs, low specific leaf mass, low leaf area ratio, high root-to-shoot ratios, and low whole-plant carbon gain). The expression of these traits supports the dichotomy between shade-tolerant vs. light-demanding species because it represents a trade-off in carbon investment. In an environment where overall resources (light and nutrients) are scarce, plants allocate more to defenses than plants specialized in exploiting high-light conditions and nutrient pulses in gaps. Maternal effects on seedlings also determine seedling structure and function. Many shade-tolerant species have large seeds, and thus, are able to produce large seedlings that require more structural support, and have low leaf area ratio and specific leaf mass (Poorter \& Rose, 2005).

The survival capacity of shade-tolerant seedlings is associated with structural characters providing resistance to physical damage, such as stem and leaf tissue density (Alvarez-Clare \& Kitajima, 2009). Shade-tolerant species are structurally better defended than light-demanding species, even in very young seedlings, although this comes at a price of slow growth and slow biomass accumulation (Kitajima, 1994). Structural traits are correlated with large seeds and large seedling sizes, the presence of storage cotyledons, carbohydrate reserves associated with shade tolerance (Wright et al., 2010), and the long-term survival of seedlings and saplings under shade (Kitajima \& Poorter, 2010). Stress tolerance is thus associated with the level of available resources and explains patterns of seedling survival in the shade, and strategies facilitating initial habitat colonization and determining patterns of species distribution and abundance in gradients of light availability. 
The carbon gain model: This model was proposed by Givnish (1988) who provides a holistic overview of how plants adapt to changing light conditions. Givnish (1988) suggested the examination of integrated responses at the organismic level to changes in the light environment, rather than examining minute, isolated physiological processes at the leaf level. The fundamental concept of Givnish (1988) is that plant responses are contextdependent (including the physical and the biological environment) and are adaptive in the sense that natural selection will favor the maximization of carbon gain in congruence with resource quality following a cost/benefit model. In other words, maximization of carbon gain under low light requires a strategy of resource investment with adaptive benefits in the long run. Under restricted light, plants will show a shade-adapted phenotype characterized by slow growth, low photosynthetic rates, low leaf area ratio, and low specific leaf mass. This phenotype is more advantageous compared to that of light-demanding species under shade. Givnish (1988) emphasizes the examination of the impact of individual functional traits on whole-plant performance, opening the possibility of analyzing integrated responses to multiple stressors, not only to low light. Since the carbon gain model integrates responses over time and considers whole plant allocation and allometric strategies, the consistency of this model with instantaneous and short-term measurements of photosynthetic performance is limited.

CSR (competitor, stress tolerator, ruderal) model: This model links a plant's strategy, or syndrome, with functional performance and population biology, and recognizes strategies of evolutionary specialization associated with stress responses (Grime, 1989). Following classic CSR theory (competitor, stress tolerator, ruderal) shade tolerants are classified as "stress tolerators". However, Grime (1977) distinguishes several alternative strategies depending on the relative importance of competitive interactions, stress conditions, and disturbance, positioning plants inside a triangle determined by the relative importance of these three factors. For instance, a plant exposed to a habitat with a high level of disturbance and low stress will likely develop the "R" or "ruderal" strategy, in other words, will evolve to benefit from frequent disturbances characterized by initial low competition and lack of environmental stresses. The classification could include many combinations of the CSR continuum, giving room for niche divergence along these three axes. One appealing attribute of this model is its simplicity and generality. Grime accommodates for a continuum of responses since the three main axes correspond to continuous variables, and thus, the position of a plant species within the triangle can be temporary, giving room for ontogenetic adaptation and size-mediated (or allometric) responses (Weiner, 2004). This possibility accommodates some of the major criticisms of this model (Craine, 2007), including the static categorization of plant strategies and the lack of consideration of scenarios in which plants move out of the shade and acquire a different strategy. The intensity of competition, environmental stresses, and disturbance also covary across space and time. Finally, transient combinations of this model, as dependent on ontogeny, could lead to acclimation to different stress factors, in addition to light acclimation (Kozlowski \& Pallardy, 2002). The debate about the functionality of the CSR approach still continues (Craine, 2005, 2007; Grime, 2007).

Resource competition model: This model is based on Tilman's $(1977,1990)$ notion of asymmetric or exploitative resource competition. As in the case of Givnish (1988), Tilman's work was generated in temperate areas in simpler systems under controlled conditions very different from tropical communities. However, the conclusions of such studies can be applied to the analysis of succession in tropical rain forests, especially in the early successional stages when seed dispersal and seedling spatial distribution are critical. Given two competing species, the winner is the species able to survive 
with the least resource requirements. Species diverge in resource use through the expression of different tolerances for a lower amount of the resource compared to competing species. Furthermore, a species can be a good competitor for one resource, but it might not be as good a competitor in other aspects of the competitive performance, such as dispersing seeds or fighting predators. Different species express a variety of tolerances for lower amounts of available resources (see Rees, Condit, Crawley, Pacala, \& Tilman, 2001). There is an evident similitude of this model with the recruitment limitation and neutral models of species diversity in tropical rain forests (Hubbell et al., 1999). Competing species balance out their shortcomings by exploiting alternative resources along the environmental gradient. In tropical rain forests, the limiting common resource is light. Divergence takes place because plants differ in their light limitation and because plants develop alternative adaptations to decreased light, such as increased allocation to light interception, increased constructions costs, or better herbivore defenses. As discussed by Kitajima \& Poorter (2008) the competitive advantage of one species over another along the light gradient is affected by stochastic factors (gaps, mechanical damage) and trade-offs allowing plants to exploit different levels of the light resource at the seedling stage (and throughout ontogeny in general). Light competition forms the basis of divergence along the regeneration niche (Pacala \& Rees, 1998), but other limiting resources, such as nitrogen availability, affect plant performance and influence how plants partition the light resource (Campo \& Vázquez-Yanes, 2004).

\section{THE REACTION NORM APPROACH (GRADIENT ANALYSIS) AS A FRAMEWORK TO UNDERSTAND SHADE TOLERANCE}

The rich environmental complexity of tropical rain forests rests on the temporal and spatial dynamics of the aperture of canopy gaps, which constitute one of the main ecological mechanisms responsible for the maintenance of a high level of species diversity (Rosindell, Hubbell, \& Etienne, 2011). By creating heterogeneous conditions and influencing resource distribution (especially of light and nutrients; Prescott, 2002), gaps influence stochastic and biotic factors, facilitating the coexistence of species with different regeneration niches that specialize in a narrow portion of the gradient (Poorter, 2007; Wright et al., 2010). This mechanism constitutes the "gap hypothesis" of species diversity (Schnitzer, Mascaro, \& Carson, 2008). Therefore, multiple regeneration niches are possible given the high number of plant species, ontogenetic stages, and life forms distributed over a complex environmental gradient, which filters species based on their capacity to withstand gaps of different sizes and shaded understories. Although variation in the regeneration niche is clearly continuous (i.e., Augspurger, 1984), the literature (i.e., Swaine \& Whitmore, 1988) has traditionally divided plant species into two opposing groups: shade-tolerant (late successional or climax) and light-demanding species (early successional, gap-dependent, shade-avoiders, nomads, or pioneers). This classification is biased towards the segregation of tree seedlings along the light gradient based on physiological and demographic trade-offs between slow growth and low mortality in the shade vs. fast growth and high mortality under sun (Kitajima \& Poorter, 2008). This classification has rarely considered other life stages and life forms and regards light as the primary limiting factor, although changes in forest structure affect the distribution of other critical plant resources such as nutrients and water, vapor pressure deficit, humidity, and temperature (Guariguata \& Ostertag, 2001). Although over simplistic, the classification has practical significance since it guides forest restoration and management practices. However, it should not override the dynamic nature of a species' regeneration niche, which follows an ontogenetic trajectory over time (Clark \& Clark, 1992). Many species could adjust or even reverse their regeneration niche during their ontogeny (Dalling et al., 2001; Poorter, 
Bongers, Sterck, \& Wöll, 2005); whereas other species have intermediate light requirements and benefit from moderate light increases early in life (Augspurger, 1984; Wright, MullerLandau, Condit, \& Hubbell, 2003). There is evidence for ontogenetic concordance (i.e., the fundamental regeneration niche is conserved throughout ontogeny; Gilbert, Wright, MullerLandau, Kitajima, \& Hernandéz, 2006; Poorter, 2007; Kitajima \& Poorter, 2008; Avalos \& Mulkey, 2014), although the expression of ontogenetic niche shifts could be the standard (Poorter et al., 2005; Gilbert et al., 2006), despite the paucity of data on the variation in microsite conditions and how it determines the growth responses of ontogenetic stages other than seedlings and adults (MartínezRamos, Alvarez-Buylla, \& Sarukhan, 1989; Clark \& Clark, 1992; Niinemets, 2006; Wright et al., 2010).

The regeneration niche is multifactorial and is contingent on the combination of multiple functional traits whose expression varies ontogenetically (Schlichting \& Pigliucci, 1998). The application of the reaction norm approach or gradient analysis (i.e., the examination of the temporal phenotypic expression of genotypes across environmental gradients) provides a suitable framework to understand how plants adapt to complex environments and how suites of functional traits vary with ontogeny and environmental conditions. Reaction norms serve to analyze the expression of plasticity and integrate complex suites of functional traits that shape particular life history strategies (Weiner, 2004).

Since the seminal paper of Arnold (1983), plant ecophysiologists have analyzed adaptation as the integration of suites of functional traits responding to environmental changes and determining physiological performance (survival, growth, reproduction, and overall fitness). Natural selection filters the most advantageous phenotypes under a given set of environmental conditions resulting in adaptive evolution. This represents the central mechanism linking functional traits with evolutionary biology (West-Eberhard, 2003; McGill,
Enquist, Weiher, \& Westoby, 2006), and facilitating the exploration of plastic responses without having to replicate genotypes across environments (Valladares et al., 2006). In this manner, individual phenotypic variation is directly connected to functional performance in a given environment, and thus, is tied to natural selection, and eventually, adaptation. Since functional performance changes across ontogeny and varies following spatial and temporal gradients in resource distribution, it is evident that ecophysiological studies must consider integrated responses at the whole organismic level to determine how sets of functional traits co-vary following a reaction norm across the successional gradient, and how the adjustment capacity is affected by ontogeny (Givnish, 1988). This research implies considerable logistic challenges for species with long lifespans and complex spatial distributions, and for growth forms not easily accessible for longterm observation (i.e., canopy trees, lianas, and epiphytes; Clark \& Clark, 1992; Condit, Hubbell, \& Foster, 1996; Hubbell et al., 1999).

\section{LIFE CYCLE SUCCESSIONAL TRAJECTORY MODEL OF GÓMEZ-POMPA \& VÁZQUEZ-YANES}

Communities are complex entities. Since organisms of different taxonomic groups are assembled along multiple environmental scales, their delimitation in the field can be controversial. The fundamental question is "what is a community"? A community is a system composed of taxonomic entities interacting through the exchange of resources across spatial and temporal gradients (Vellend, 2010), which determines the dynamics of species colonization, establishment, and loss. Resource limitation can be represented by light, nutrient availability, or water seasonality. Resource gradients make communities more than a random collection of artifacts, although their limits are difficult to determine since they are open systems and involve a variety of organisms from different taxonomic groups. The study of communities goes to the heart of ecology by 
observing the factors controlling species diversity, distribution, abundance, and composition (Vellend, 2010).

Many variables interact in the analysis of community assembly, such as site-specific factors, the type and intensity of previous land use, the nature and dynamics of the disturbance regime, and the nature of the landscape matrix (Guariguata \& Ostertag, 2001; Chazdon, 2008). All these factors influence species composition and abundance, as well as the distribution of functional traits, variation in population dynamics, and competitive interactions. The complex interaction between these factors makes it challenging to identify the dominant patterns explaining the nature of the community, especially through the analysis of succession (but see Chazdon, 2008, 2014), and makes it difficult to predict the final successional trajectory in tropical rain forests (Peterson \& Carson, 2008). However, to understand the relevance of shade tolerance it is necessary to comprehend the fundamental mechanisms of tropical rain forest succession.

Models explaining tropical rain forest succession are rooted in the first theories of modern ecology proposed to explain the nature of plant communities (i.e., Gleason, 1926; Clements, 1936). Ecologists trained in temperate areas (for instance, Richards, 1952) extended these ideas to the analysis of forest succession in the tropics. They expected to observe predictable successional trajectories characterized by a progressive transition through identifiable stages towards the climax, with sets of species replacing each other and partitioning environmental resources (in agreement with Clement's concept of communities as "superorganisms"). Despite the prevalence and popularity of Clement's ideas, the Gleasonian view of tropical plant communities, characterized by continuous variation in species composition over time (Gleason's "individualistic" view of continuous changes in community composition across environmental gradients) is closer to the high dynamism and rapid species turnover typical of tropical succession (Hubbell, 1997). The current synthesis combines deterministic (i.e., Janzen-Connell model and the regeneration niche) and stochastic models (i.e., dispersal limitation and the neutral theory of biodiversity and biogeography, Rosindell et al., 2011) to predict species diversity and community structure. It is more complex than previous models because it considers the wide variation in life cycles and successional strategies (see Norden et al., 2015). These ideas are not new (see Budowski, 1965; Gómez-Pompa \& Vázquez-Yanes, 1981), but have been incorporated into more quantitative successional models (Acevedo, Urban, \& Shugart, 1996; Ackerly \& Cornwell, 2007) and are gaining acceptance as the role of succession as a selective pressure and species filtering mechanism is better understood (Webb, Ackerly, McPeek, \& Donoghue, 2002; Letcher et al., 2015; Lohbeck et al., 2015).

Gómez-Pompa \& Vázquez-Yanes (1981) proposed a model of tropical rain forest succession based on the characteristics of the life history strategies of the dominant species at different stages of forest regrowth (Fig. 1). In this model of life cycle patterns, a species enters a successional stage depending on the match between environmental conditions and the species' physiological amplitude as influenced by ontogeny. Species arrive by dispersion or advanced regeneration (MartinezRamos \& Soto-Castro, 1993), stay for variable periods, some reproduce and complete their life cycle within a stage or across several stages, or are excluded without becoming reproductive. This model follows the Gleasonian view of forest succession, with continuous trajectories and many variable scenarios (exclusion, establishment, and permanence until reproduction spanning one or several stages). Gómez-Pompa \& Vázquez-Yanes (1981) illustrate 21 different regeneration strategies, but there could be many more. This approach emphasizes ecological roles (i.e., functional diversity) more than taxonomic identity and can accommodate redundancy since many species could occupy similar regeneration niches (Rosindel et al., 2011). This makes it congruent with models explaining community assembly based on 


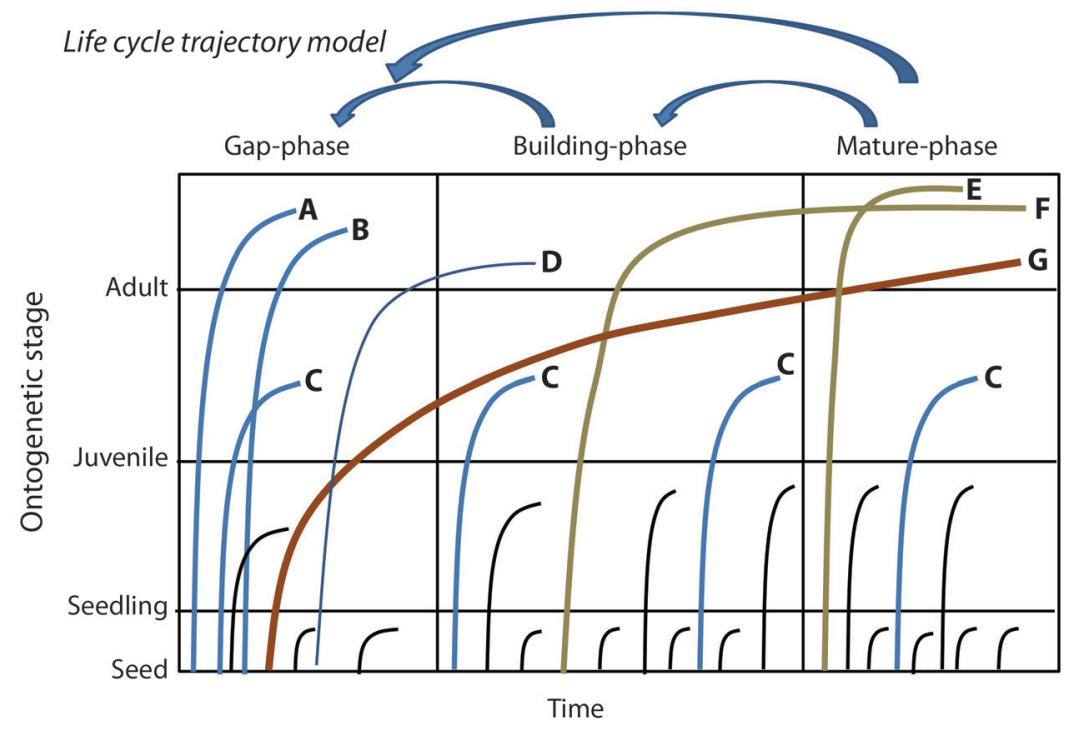

Fig. 1. Ontogenetic trajectories reflecting different regeneration niches following the progression of tropical rain forest succession over time. Each line represents a life cycle from seed to reproductive adult (some trajectories do no reach the reproductive stage and die at the seed, seedling or juvenile stage -black lines-). A complete life cycle takes place when the ontogenetic trajectory reaches the adult phase. Trajectories A and B are typical of pioneer species that complete their life cycle within the gap. Trajectory $\mathrm{C}$ reaches the juvenile phase but dies before reproduction. Trajectory $\mathrm{D}$ regenerates in the gap but persists until the building and mature phases (old-growth pioneer). Trajectory $\mathrm{E}$ is typical of shade tolerant species (these species germinate and complete their life cycle in the shade in the mature phase). F and G correspond to cryptic pioneers that start in the gap or building-phases but persist until the canopy closes, reaching reproductive stages in the mature phase. Some old-growth pioneers are functionally equivalent to cryptic pioneers ( $F$ and $G)$. Some species reach different stages by dispersion but die before reproduction. Arrows above indicate that forest succession could revert to previous stages. Modified from Gómez-Pompa \& Vázquez-Yanes (1981).

stochastic factors (i.e., Hubbell, 1997). In fact, stochastic and deterministic factors interact to determine species composition throughout succession and could have different effects depending on the successional strategy (pioneer vs. shade tolerant or old growth specialists) and the species abundance (rare species vs. second growth specialists; Kraft et al. 2008; Norden et al., 2017). Certain stages could vary in duration while being dominated by specific groups, such as lianas or palms (Schnitzer et al., 2008). The model also integrates different filters influencing species abundance (see Kraft et al., 2015), including physiological limits to withstanding the physical environment in one point of the trajectory, competitive exclusion, within-site heterogeneity favoring species co-existence, and interactions with pathogens, predators, pollinators, and dispersers. The model integrates the evolutionary consequences of variation in functional and demographic traits, and how successional habitats drive the evolution of niche divergence (Letcher et al., 2015). Similar to Gleason's ideas of continuous and complex community assembly, the life cycle model has not been given the importance it deserves in understanding forest regrowth. Current ideas incorporating the filtering role of succession on functional traits (Kraft et al. 2015) are latent in this model.

In mature tropical rain forests succession starts with a canopy disturbance (i.e., a tree fall), which significantly increases the understory light levels and creates light environments similar in magnitude to those at the surface of the canopy. This is the "initiation phase" of Oliver \& Larson (1996), also called the "gap-phase" stage of the successional cycle 
by Denslow (1987). Canopy gaps increase light and create pulses of nutrients as the subsoil is exposed by the roots of the fallen tree and debris produce an aggregation of decomposing matter (Schaetzl, Burns, Johnson, \& Small, 1988). Species partition the different parts of a gap. Brandani, Hartshorn, \& Orians (1988) found higher seedling diversity in the root section relative to the bole and crown areas of the fallen tree (higher seedling density was concentrated in the crown area). Eighty-seven percent of the tree species at La Selva, Costa Rica, were found as seedlings in the 51 gaps examined in this study. Most species started as colonizers rather than as gap survivors, showing that the majority of species require a gap to regenerate. Partitioning of microsite conditions also takes place in the understory under deep shade (Montgomery \& Chazdon, 2002) demonstrating that species divergence along fine resource gradients is not limited to gaps (Svenning, 1999).

In addition to the strong colonization ability by pioneers (small seeds produced and dispersed in large numbers, low wood density, low specific leaf mass), recently dispersed seeds, and seeds stored in the seed bank, begin to germinate, creating a carpet of seedlings which eventually leads to high rates of seed and seedling mortality (Schupp, Howe, Augspurger, \& Levey, 1989). High levels of seedling mortality do not impede the dominance of pioneers in the first stages of gap colonization. However, over time, seed and seedling mortality increases in the shade due to the combined action of limited resources (light and nutrients) and pathogens (Augspurger, 1984). Some of the species arriving first include cryptic pioneers, which start germination and establishment under disturbed conditions but can withstand shade once the canopy closes. Here, increased light and nutrients lead to a switch in biomass allocation, architecture and growth (Niinemets, 2010b). In these species, sudden peaks in resources shift the regeneration niche from shade tolerance to gap specialization. Some shade-tolerant species eventually get excluded from this phase due to increased photodamage or competition with fast-growing pioneers.

As the gap fills, the forest reaches the "building, stand-thinning, or stem exclusion phase" of pioneers following Oliver and Larson (1996) and Chazdon (2008). In this stage, the canopy, initially composed by pioneer species, gets denser as pioneers reach their reproductive stage and pre-empt the light conditions for additional pioneer seedlings and favor the establishment of shade-tolerant species characterized by large seeds, high wood density, high leaf specific mass, low photosynthetic rates, and slow growth. Shade tolerants increase in abundance and dominance, leading to a gradual exclusion of pioneers and lianas. As succession progresses, there is a change in the species pool as well as in the diversity of functional traits (Boukili \& Chazdon, 2017; Plourde, Boukili, \& Chazdon, 2015). Functional diversity peaks at intermediate stages of succession when pioneers still co-occur with shade-tolerants (Muscarella et al. 2016).

During the "mature or old growth stage" of forest succession, shade-tolerants reach the canopy and become dominants in this stratum. Shade tolerants transition from the lightdeprived conditions of the forest understory to the canopy, which implies changes in biomass allocation, growth strategies, and physiological adjustment (i.e., niche shifts, Niinemets, $2010 \mathrm{~b}$ ). The documentation of the mechanisms of ontogenetic adjustment at this point is still scarce (but see Poorter et al., 2008; Wright et al., 2010).

Cryptic pioneer species present an example of the transition from pioneers to shade tolerants. Seedlings of the palm Euterpe precatoria are abundant in light gaps and disturbed environments (Avalos, Fernández, \& Engeln, 2013) but remain suppressed for long periods under shade once the canopy closes. This palm becomes reproductive in 93-158 years under shade (Peña-Claros \& Zuidema, 2000), but under semi-open conditions (clearings and forest edges), reproductive stages are reached in just four years (Avalos, 2016). Variations in the regeneration trajectories could depart 
from this expected successional sequence. Typically, pioneers invade recent gaps, but are eventually replaced by shade-tolerants when the canopy closes and when the canopy of short-lived pioneers creates increased shade. Long-lived pioneers are finally excluded due to shade conditions prevalent during late succession and are replaced by long-lived trees that started as shade tolerants (Gómez-Pompa \& Vázquez-Yanes, 1981). Long-lived shade tolerants dominate the canopy during late stages by positioning their crowns in sun-exposed sites. It is likely that these species express reverse ontogenetic niche shifts once light conditions improve (Clark \& Clark, 1992; Dalling et al., 2001). More long-term data on the growth performance of life stages intermediate between seedlings and adults is necessary to fully understand the physiological mechanisms involved in the transition from strictly shade tolerant into canopy plants (but see Wright et al., 2010).

The life cycle trajectory model of GómezPompa and Vázquez-Yanes (1981) reflects the continuity of the pioneer-shade-tolerant classification, and the diversity of alternative regeneration strategies entering into the succession continuum. It also offers a framework to understand other aspects of functional ecology, such as the distribution and diversity of functional traits, and how the strength of herbivoreplant interactions, competition, and parasitism varies during succession. For instance, more diverse plant assemblages give room for more diverse plant herbivores eventually leading to more diverse chemical and structural defenses.

\section{AREAS FOR FUTURE RESEARCH}

Increased representation of microhabitats, ontogenetic stages, and life forms where shade tolerance is critical: Analogous to the concentration of research on shade tolerance in the rain forest understory and on a limited range of life stages and life forms (tree seedlings and saplings), little attention has been given to shaded environments in other parts of the forest profile, such as the canopy itself. The canopy controls the light conditions of the forest understory, and it is usually assumed that canopy plants are not light-limited. In fact, the leaf distribution in the canopy can be highly heterogeneous, which in turn affects light distribution from the canopy surface down to the forest floor (Kitajima, Mulkey, \& Wright, 2004; Avalos, Mulkey, Kitajima, \& Wright, 2007). Since forest canopies are multi-layered, light distribution follows the complex stratification of leaf mass. Light extinction takes place immediately below the canopy surface, decreasing to $4-9 \%$ of the light magnitude measured at the canopy surface in places dominated by lianas (Avalos, Mulkey, Kitajima, \& Wright, 2007). Liana foliage has different optical properties relative to leaves of supporting trees (high leaf absorbance, low transmittance; Avalos. Mulkey, \& Kitajima, 1999) creating light levels similar to those of the understory (Chazdon \& Fetcher, 1984; Chazdon, Pearcy, Lee, \& Fetcher, 1996). This light deprivation could take place over a few days, as the liana produces a thick monolayer of foliage on top of canopy trees (Avalos, Mulkey, Kitajima, \& Wright, 2007). The response of canopy trees to very dark microhabitats created by lianas is still poorly understood, but it entails decreased leaf lifespan for the host tree, and changes in biomass allocation to increase leaf production in sites of the tree crown with more access to light. The distribution of leaf masses from different species and life forms follows a temporal trajectory determined by leaf phenology and changes in forest structure (Sapijanskas, Paquette, Potvin, Kunert, \& Loreau, 2014) favoring niche divergence through functional complementarity and plasticity. Adaptation to changing light conditions within the canopy, not to mention the functional and communitylevel consequences of adaptation to different canopy positions, remains an open area for research (but see Cardelús \& Chazdon, 2005). Other canopy life forms such as epiphytes show little changes in structure and function when exposed to deep shade in comparison with high light environments (Benzing, 2008). Research on epiphyte adaptation to the canopy is biased towards sites of greater light exposure, whereas 
there should be greater amplitude of research on epiphytes in different light preferences because of their considerable species diversity (20-25 000 species, mostly concentrated in the tropics; Benzing, 2008). Instead, shade tolerance in epiphytes is poorly understood (Zotz \& Hietz, 2001), and its effect tends to be confounded with photoinhibition or water stress. Epiphytic bromeliads, for instance, evolved from sun-exposed environments and moved up colonizing the top of the canopy, whereas shade adaptations evolved secondarily, facilitating the colonization of understory habitats (Crayn, Winter, \& Smith, 2004). The ecological and evolutionary analysis of shade tolerance in epiphytes is long overdue.

Determination of the molecular and genetic basis of shade tolerance to understand its evolution: Although many functional traits are very labile, and thus, show almost immediate adaptation to sudden changes in resource distribution (i.e., stomatal conductance and photosynthetic induction), their variation over evolutionary time is very conservative (Webb, 2000; Donoghue, 2008; Letcher et al., 2015). This explains why species with similar ecological requirements are phylogenetically related and tend to select similar habitats (Webb, 2000). Phylogenetic analyses are critical to understand the variation in species divergence in functional traits and their role in facilitating adaptation to heterogeneous conditions. This can lead to the selection of suitable study systems to explore the phylogenetic relatedness of plants exploiting shaded environments. This has been attempted (Letcher et al., 2015), but results are still inconclusive due to the high lability of functional traits; existent phylogenetic and successional studies often consider such traits as static or particular to a set of species without accounting for ontogeny (Letcher, 2010; Chazdon et al., 2011). Finally, the molecular regulation of shade tolerance requires more attention (Gommers et al., 2013), especially regarding the expression of physiological pathways influencing plant morphology and overall biomass allocation (i.e., photochromic and hormonal control of growth responses).

Refined analyses of the regeneration niche and ontogenetic niche shifts based on functional traits: Many functional traits contribute to shade tolerance (Valladares \& Niinemets, 2008) and are partially responsible for the final expression of a shade-adapted syndrome. Water and nutrient availability, competitive interactions, and resistance to pathogens and herbivores also influence shade adaptation. As mentioned above, traits related to the capacity to grow under shade are efficient proxies to measure the degree of shade tolerance. Our understanding of the importance of specific functional traits, and combinations of suites of functional traits, depends on the implementation of long-term demographic studies based on population models having sufficient replicates of ontogenetic stages, light conditions, and life forms, while being able to correct for phylogenetic bias. Such studies face significant challenges in environments where most species are rare, hyper-dispersed, widely distributed across the forest profile, and where many ontogenetic stages are not amenable for experimental manipulation or have very long duration. The studies of Clark and Clark (1992), Poorter et al. (2008) and Wright et al. (2010) are steps in the right direction. These studies compared multiple sites, analyzed longterm data (including metadata), and determined how functional traits covary within and among life stages in tropical forest plants. Wright et al. (2010) analyzed the survival-growth trade-off using multiple functional traits in 103 tree species, from seedlings to adults, within the $50 \mathrm{Ha}$ plot of Barro Colorado Island in Panama. As plants traverse different light conditions from the understory to the canopy and transition from seedlings and saplings to adults, the covariant nature and relative importance of suites of functional characters changed, providing evidence for ontogenetic niche shifts in many species (congruent with the general results of Clark \& Clark, 1992, and Poorter et al., 2008). Wright et al. (2010) reported a strong effect of 
the growth-survival trade-off in saplings when amplifying the differences by including the growth rates of the fastest growing individuals and the mortality rates of the slowest growing individuals. For trees, the growth-survival trade-off was weak. In addition to the changing matrix of functional traits through ontogeny, Wright et al. (2010) conclude that most functional traits function as proxies of the underlying demographic factors that determine carbon allocation (such as the intrinsic rate of increase) which are more likely to affect adaptation to changing light conditions.

The above-mentioned studies stress the importance of ontogenetic variation in functional traits. Traits that are critical in a given ontogenetic stage may have a negligible effect at another stage. Poorter et al. (2008) and Wright et al. (2010) report a strong negative correlation between wood density and growth rates across all ontogenetic stages, however some functional traits have proportionally more importance in seedlings than in mature trees, such as leaf-level traits (i.e., specific leaf mass). In dicotyledonous species with secondary growth, wood density can reflect the capacity to resist mechanical and herbivore damage and the plant's capacity for biomass accumulation (Chave et al., 2009), and thus, the plant's shade tolerance (Alvarez-Clare \& Kitajima, 2009). Despite its clear importance and its wide use as a proxy of plant growth, wood density is not necessarily a universal predictor of performance across all life forms. The variation in wood density is a poor predictor of biomass accumulation and carbon sequestration in understory, subcanopy and canopy palms (Cambronero, Avalos, \& Alvarez-Vergnani, 2018) and is unlikely to be an efficient functional character related to the growth and survival trade-off in plants lacking secondary growth.

We still know relatively little about the link between demographic parameters and functional traits and how they covary among critical ontogenetic stages (i.e., seedlings) and life forms (but see Santiago \& Wright, 2007), or the strength of their phylogenetic signal during succession (Swenson et al., 2012). Demographic studies could contribute significantly to our understanding of forest succession by integrating functional traits with the carbon accumulation capacity in critical ontogenetic stages and by explaining the impact of differences in resource quality on demographic parameters throughout ontogeny. Finally, since the phylogenies of many plant groups are particularly well known, we should integrate phylogenetic information in the analysis of shade tolerance. Despite the ample range of plant species included in Poorter et al. (2008) and Wright et al. (2010) studies, there was no correction for phylogenetic bias. In contrast, the Swenson et al. (2012) study compared the mature forest within the $50 \mathrm{Ha}$ plot of Barro Colorado Island in Panama with the much disturbed, less diverse, and much smaller Luquillo Forest Dynamics Plot (16 Ha) incorporating the effect of phylogenetic and functional structure on community assembly. They found species turnover and functional diversity to be driven mainly by environmental filtering, whereas phylogeny had a weak effect. However, their sampling was limited to plants $>1 \mathrm{~cm}$ in diameter, and thus, seedlings were not considered.

\section{Application of a systems perspective integrating a broader geographical range and long-term data to facilitate comparisons and the development of a new synthesis:} A holistic perspective integrating a systems approach to succession and incorporating many of the emerging properties of biological systems (self-organization and uncertainty) is necessary to identify common patterns and account for significant variability in the successional processes. This requires more interaction among fields that traditionally have looked at patterns of species diversity and species composition throughout succession from different perspectives, methodologies, and spatial and temporal scales, such as evolutionary biology and community ecology (Urban, et al. 2008). Considering different scales is of utmost importance, since patterns of trait distribution, species composition, and phylogeny change 
with the scale. The core processes determining community assembly are drift (which combines neutral and stochastic processes), selection (niche filtering), dispersal (combination of probabilistic and environmental filtering), and speciation (evolution of the species pool). The interactions among these four elements are rooted on organismal performance, but vary across levels of organization, from individual plants to regional and landscape levels, determining community composition in the long run (Vellend, 2010). Chronosequence studies (Chazdon, 2008; Craven, Hall, Berlyn, Ashton, \& van Breugel, 2015), as well as the monitoring of large tropical forest dynamics plots (see Zimmerman, Thompson, \& Brokaw, 2008), have the potential of disentangling the relationships among these core processes, and thus to explain the observed patterns of community assembly at different levels of complexity (Vellend, 2010; Meiners, Cadotte, Fridley, Pickett, \& Walker, 2015). For instance, chronosequence studies at different geographical scales have helped to explain how much of the variation in species composition and abundance is determined by the site age relative to local environmental conditions and initial species composition (Letcher et al., 2012; Mesquita, Massoca, Jakovac, Bentos, \& Williamson, 2015). Craven et al. (2015) reported shifts in functional characters during succession. For instance, leaf toughness, wood density, and adult plant size increased significantly whereas photosynthetic rates decreased in more mature stages of secondary forests in Soberanía National Park in Panama. Norden et al. (2015) found that site identity explained most of the variation in species density and basal area in successional plots from Brazil, Costa Rica, Mexico, and Nicaragua. They conclude that random factors were more important than stand age or previous land use in predicting species composition (there was high among-plot variation in species composition even for plots within a site). This suggests that local effects, such as the landscape and the regional species pool, could affect species composition within a plot, and influence the dynamics of the successional process in sites of similar environmental conditions (Guariguata, \& Ostertag, 2001). This result shows the importance of having large reserves to capture a significant component of the previous species diversity found in larger tracts of tropical rain forests. Long-term data from permanent plots could help to elucidate the role of stochastic and deterministic factors affecting species trajectories, species identities, and functional roles (i.e., the increased abundance of shade-tolerants as succession progresses). Such studies could help to clarify the influence of species diversity (taxonomic and functional diversity) on ecosystem functions such as carbon sequestration.

\section{CONCLUDING REMARKS}

Shade tolerance remains a central concept in tropical rain forest succession critical to understanding the evolutionary and ecological limits of niche diversification. From seed dispersal and seedling establishment to the development of the reproductive adult, tropical plants experience a complex light gradient as succession progresses, with dynamic interactions among competitors, pathogens, herbivores, pollinators, and seed dispersers. Although the initial physical conditions of early successional stages are critical in determining their response at later stages (i.e., Poorter, 2007), the environment faced by more mature ontogenetic stages also impacts growth, reproduction, and survival, the three components of functional performance (Violle et al., 2007). The paucity of data on ontogenetic niche shifts, and the characterization of environmental conditions encountered by mature ontogenetic stages, continues to be a major research gap.

The analysis of shade tolerance should be part of more general, inclusive models, such as the life cycle successional trajectory model, which look for common strategies to explain resource use, encompassing the analysis of ecophysiological mechanisms of resource utilization, life history strategies, and demographic responses from cells to individuals, populations, communities, and ecosystems (i.e., by 
increasing comparative studies of contrasting ecosystems to find common emerging strategies, see Lebrija-Trejos, Pérez-García, Meave, Bongers, \& Poorter, 2010; Lohbeck et al., 2015). Novel, integrative approaches, such as the leaf and whole-plant economic spectrum, have great potential to generate a new synthesis beyond community assembly rules (and thus, go beyond the examination of regeneration niches), and are sufficiently general to describe the consequences of differences in functional performance on ecosystem processes (Wright et al., 2004; Reich, 2014). Such new synthesis should rest on a robust understanding of the impacts of functional traits on plant fitness. The accumulation of long-term data on forest growth and changes in ontogenetic performance (Poorter et al., 2008; Wright et al., 2010) could provide the necessary evidence to validate the plant-economics spectrum model. This new approach requires a change of paradigms. McGill et al. (2006) propose a switch from more descriptive to more mechanistic views of plant performance based on functional traits.

The generation of this information has never been more urgent than now, considering that many human impacts on natural systems are becoming global as reflected in the fast progression of climate change. Climate change is likely to impact more intensively shade tolerant species, and in general, species exploiting limited resources and having slow response times and limited temporal plasticity. Our capacity to conserve, manage and restore tropical diversity will benefit from a mechanistic understanding of plant adaptation to successional gradients, especially now that light changes are compounded by increased resource scarcity and water stress (Schwalm et al., 2017) triggered by more intense climatic fluctuations (Clark, Clark, \& Oberbauer, 2010).

Declaración de ética: el autor declara que está de acuerdo con esta publicación; que no existe conflicto de interés de ningún tipo; y que ha cumplido con todos los requisitos y procedimientos éticos y legales pertinentes. Todas las fuentes de financiamiento se detallan plena y claramente en la sección de agradecimientos. El respectivo documento legal firmado se encuentra en los archivos de la revista.

\section{ACKNOWLEDGEMENTS}

Olivia Sylvester, Silvia Alvarez-Clare, Robin Chazdon, Pat Heslop-Harrison and two anonymous reviewers provided healthy criticisms that improved this manuscript. Catie Morris corrected the final version of the manuscript.

\section{RESUMEN}

Tolerancia a la sombra en el contexto del proceso de sucesión en los bosques tropicales lluviosos. La tolerancia a la sombra (la capacidad de sobrevivir y crecer durante largos períodos bajo sombra profunda) es un componente clave del valor adaptativo de la planta y la base de las teorías actuales de la sucesión forestal de la selva tropical. Sirve como un paradigma para entender la asignación óptima de recursos limitados bajo regímenes dinámicos de luz. En esta revisión analizo cómo la sucesión de los bosques tropicales lluviosos influye en la expresión de los mecanismos ecofisiológicos que conducen a la tolerancia a la sombra, e identifico áreas futuras que pueden aumentar nuestra comprensión de las consecuencias ecológicas y evolutivas de este fenómeno. La tolerancia a la sombra es un rasgo funcional continuo y multivariable que refleja el balance de invertir recursos bajo condiciones de luz limitada versus crecer más rápidamente en condiciones de luz intensa. Propongo el modelo de ciclo de vida a lo largo de la trayectoria de sucesión de Gómez-Pompa y VázquezYanes como una herramienta integradora para entender la sucesión de la selva tropical. Este modelo muestra cómo las especies se distribuyen a lo largo del gradiente ambiental en función de su grado de tolerancia a la sombra, y representa un paradigma más integrador para comprender la interacción entre los diferentes componentes de la diversidad de especies (diversidad taxonómica y funcional y variación ontogenética) a lo largo de la sucesión. El modelo propone que las diferentes combinaciones de caracteres funcionales que determinan la tolerancia a la sombra se expresan en diferentes etapas del ciclo de vida, y afectan cómo y cuándo las plantas ingresan en el proceso de sucesión. Los modelos que explican la expresión de tolerancia a la sombra (disponibilidad de recursos, ganancia de carbono, CSR, competencia de recursos) se basan en la economía de toda la planta y no son mutuamente excluyentes. Se están desarrollando explicaciones más integradoras basadas en la distribución de caracteres funcionales entre especies, etapas ontogenéticas, y micrositios, mediante el uso de estudios de cronosecuencia y metadatos colectados a largo 
plazo. El análisis de la tolerancia a la sombra está sesgado hacia las plántulas de árboles y el sotobosque. Otras formas de vida y microhábitats dentro del perfil del bosque están casi excluidas de estos análisis. En resumen, la tolerancia a la sombra es un fenómeno complejo, está determinada por múltiples caracteres funcionales que cambian ontogenéticamente en el espacio y el tiempo, e implica una considerable plasticidad. Los métodos actuales no toman en cuenta esta plasticidad. Comprender la naturaleza de la tolerancia a la sombra y su base funcional es fundamental para entender el crecimiento de la planta y mejorar la gestión, restauración, y conservación de los bosques tropicales, los cuales enfrentan las amenazas combinadas del calentamiento global y la pérdida de hábitat.

Palabras clave: filtrado ambiental; cambios de nicho ontogenéticos; caracteres funcionales; diferenciación de nicho; espectro económico foliar; espectro de economía de plantas; nicho de regeneración; sucesión secundaria; tolerancia a la sombra.

\section{REFERENCES}

Acevedo, M. F., Urban, D. L., \& Shugart H. H. (1996). Models of forest dynamics based on roles of tree species. Ecological Modeling, 87(1-3), 267-284.

Ackerly, D. D. (2003). Community assembly, niche conservatism, and adaptive evolution in changing environments. International Journal of Plant Sciences, $K(\mathrm{~S} 3), \mathrm{S} 165-\mathrm{S} 184$.

Ackerly, D. D., \& Cornwell, W.K. (2007). A trait-based approach to community assembly: partitioning of species trait values into within-and among-community components. Ecology Letters, 10(2), 135-145.

Álvarez-Clare, S., \& Avalos, G. (2007). Light interception efficiency of the understory palm Calyptrogyne ghiesbreghtiana under deep shade conditions. Ecotropica, 13, 1-8.

Álvarez-Clare, S., \& Kitajima, K. (2009). Susceptibility of tree seedlings to biotic and abiotic hazards in the understory of a moist tropical forest in Panama. Biotropica, 41(1), 47-56.

Arnold, S. J. (1983). Morphology, performance and fitness. American Zoologist, 23(2), 347-361.

Arroyo-Rodríguez, V., Melo, F. P., Martínez-Ramos, M., Bongers, F., Chazdon, R. L., Meave, J. A., ... \& Tabarelli, M. (2017). Multiple successional pathways in human-modified tropical landscapes: new insights from forest succession, forest fragmentation and landscape ecology research. Biological Reviews, 92(1), 326-340.
Augspurger, C. K. (1984). Light requirements of neotropical tree seedlings: a comparative study of growth and survival. Journal of Ecology, 72(3), 777-795.

Avalos, G. (2016). Growth of the neotropical palm Euterpe precatoria Mart. in an agroforestry system in Costa Rica. Brenesia, 85-86, 1-8.

Avalos, G., Fernández, M., \& Engeln, J. T. (2013). Successional stage, fragmentation and exposure to extraction influence the population structure of Euterpe precatoria (Arecaeae). Revista de Biología Tropical, 61(3), 1415-1424.

Avalos, G., \& Mulkey, S. S. (2014). Photosynthetic and morphological acclimation of seedlings of tropical lianas to changes in the light environment. American Journal of Botany, 101(12), 2088-2096.

Avalos, G., Mulkey, S. S., \& Kitajima, K. (1999). Leaf optical properties of trees and lianas in the outer canopy of a tropical dry forest. Biotropica, 31(3), 517-520.

Avalos, G., Mulkey, S. S., Kitajima, K, \& Wright, S.J. (2007). Colonization strategies of two liana species in a tropical dry forest canopy. Biotropica, 39(3), 393-399.

Baltzer, J. L., \& Thomas, S. C. (2007). Determinants of whole-plant light requirements in Bornean rain forest tree saplings. Journal of Ecology, 95(6), 1208-1221.

Bazzaz, F. A., Chiariello, N. R., Coley, P. D., \& Pitelka, L. F. (1987). Allocating resources to reproduction and defense. BioScience, 37(1), 58-67.

Benzing, D. H. (2008). Vascular epiphytes: general biology and related biota. Cambridge: Cambridge University Press.

Boege, K., \& Marquis, R. J. (2005). Facing herbivory as you grow up: the ontogeny of resistance in plants. Trends in Ecology \& Evolution, 20(8), 441-448.

Boukili, V. K., \& Chazdon, R. L. (2017). Environmental filtering, local site factors and landscape context drive changes in functional trait composition during tropical forest succession. Perspectives in Plant Ecology, Evolution and Systematics, 24, 37-47.

Bradshaw, C. J., Sodhi, N. S., \& Brook, B. W. (2009). Tropical turmoil: a biodiversity tragedy in progress. Frontiers in Ecology and the Environment, 7(2), 79-87.

Brandani, A., Hartshorn, G. S., \& Orians, G. H. (1988). Internal heterogeneity of gaps and species richness in Costa Rican tropical wet forest. Journal of Tropical Ecology, 4(2), 99-119.

Budowski, G. (1965). Distribution of tropical American rain forest species in the light of successional processes. Turrialba, 15(1), 40-42. 
Cambronero, M., Avalos, G., \& Alvarez-Vergnani, C. (2018). Carbon accumulation in seven neotropical palm species from different forest strata. Palms, 62(1), 25-34

Campo, J., \& Vázquez-Yanes, C. (2004). Effects of nutrient limitation on aboveground carbon dynamics during tropical dry forest regeneration in Yucatán, Mexico. Ecosystems, 7(3), 311-319.

Cardelús, C. L., \& Chazdon, R. L. (2005). Inner-crown Microenvironments of Two Emergent Tree Species in a Lowland Wet Forest. Biotropica, 37(2), 238-244.

Chave, J., Coomes, D., Jansen, S., Lewis, S. L., Swenson, N. G., \& Zanne, A. E. (2009). Towards a worldwide wood economics spectrum. Ecology Letters, 12(4), 351-366.

Chazdon, R. L. (1985). Leaf display, canopy structure, and light interception of two understory palm species. American Journal of Botany, 72(10), 1493-1502.

Chazdon, R. L. (1986). The costs of leaf support in understory palms: economy versus safety. The American Naturalist, 127(1), 9-30.

Chazdon, R. L. (2008). Chance and determinism in tropical forest succession. In W. Carson, \& S. Schnitzer (Eds.), Tropical forest community ecology (pp. 384409). Oxford: Wiley-Blackwell.

Chazdon, R. L. (2014). Second growth: the promise of tropical forest regeneration in an age of deforestation. Chicago: University of Chicago Press.

Chazdon, R. L., Chao, A., Colwell, R. K., Lin, S. Y., Norden, N., Letcher, S. G., ... \& Arroyo, J. P. (2011). A novel statistical method for classifying habitat generalists and specialists. Ecology, 92(6), 1332-1343.

Chazdon, R. L., \& Fetcher, N. (1984). Photosynthetic light environments in a lowland tropical rain forest in Costa Rica. The Journal of Ecology, 72(2), 553-564.

Chazdon, R. L., \& Pearcy, R. W. (1991). The importance of sunflecks for forest understory plants. BioScience, 41(11), 760-766.

Chazdon, R. L., Pearcy, R. W., Lee, D. W., \& Fetcher, N. (1996). Photosynthetic responses of tropical forest plants to contrasting light environments. In S. S. Mulkey, R. L. Chazdon, \& A. P. Smith (Eds.), Tropical forest plant ecophysiology (pp. 5-55). Boston, MA: Springer.

Clark, D. B., \& Clark, D. A. (1991). Herbivores, herbivory, and plant phenology: patterns and consequences in a tropical rain-forest cycad. In P. W. Price, T. M. Lewinsohn, G. W. Fernandes, \& W. W. Benson (Eds.), Plant-animal interactions: evolutionary ecology in tropical and temperate regions (pp. 209-225). New York: John Wiley \& Sons.
Clark, D. A., \& Clark, D. B. (1992). Life history diversity of canopy and emergent trees in a neotropical rain forest. Ecological monographs, 62(3), 315-344.

Clark, D. B., Clark, D. A., \& Oberbauer, S. F. (2010). Annual wood production in a tropical rain forest in NE Costa Rica linked to climatic variation but not to increasing $\mathrm{CO}_{2}$. Global Change Biology, 16(2), 747-759.

Clements, F. E. (1936). Nature and structure of the climax. Journal of Ecology, 24(1), 252-284.

Coley, P. D., Bryant, J. P., \& Chapin, F. S. (1985). Resource availability and plant antiherbivore defense. Science, 230(4728), 895-899.

Condit, R., Hubbell, S. P., \& Foster, R. B. (1996). Changes in tree species abundance in a neotropical forest: impact of climate change. Journal of tropical ecology, 12(2), 231-256.

Craine, J. M. (2005). Reconciling plant strategy theories of Grime and Tilman. Journal of Ecology, 93(6), 1041-1052.

Craine, J. M. (2007). Plant strategy theories: replies to Grime and Tilman. Journal of Ecology, 95(2), 235-240.

Craven, D., Hall, J. S., Berlyn, G. P., Ashton, M. S., \& van Breugel, M. (2015). Changing gears during succession: shifting functional strategies in young tropical secondary forests. Oecologia, 179(1), 293-305.

Crayn, D. M., Winter, K., \& Smith, J. A. C. (2004). Multiple origins of crassulacean acid metabolism and the epiphytic habit in the Neotropical family Bromeliaceae. Proceedings of the National Academy of Sciences of the United States of America, 101(10), 3703-3708.

Diaz, S., Hodgson, J. G., Thompson, K., Cabido, M., Cornelissen, J. H. C., Jalili, A., ... \& Band, S. R. (2004). The plant traits that drive ecosystems: evidence from three continents. Journal of Vegetation Science, 15(3), 295-304.

Dalling, J. W., Winter, K., Nason, J. D., Hubbell, S. P., Murawski, D. A., \& Hamrick, J. L. (2001). The unusual life history of Alseis blackiana: a shadepersistent pioneer tree?. Ecology, 82(4), 933-945.

Denslow, J. S. (1987). Tropical rain forest gaps and tree species diversity. Annual Review of Ecology and Systematics, 18(1), 431-451.

Donoghue, M. J. (2008). A phylogenetic perspective on the distribution of plant diversity. Proceedings of the National Academy of Sciences, 105(Suppl. 1), 11549-11555. 
Gilbert, B., Wright, S. J., Muller-Landau, H. C., Kitajima, K., \& Hernandéz, A. (2006). Life history trade-offs in tropical trees and lianas. Ecology, 87(5), 1281-1288.

Givnish, T. J. (1988). Adaptation to sun and shade: a whole-plant perspective. Functional Plant Biology, 15(2), 63-92.

Givnish, T. J. (1999). On the causes of gradients in tropical tree diversity. Journal of Ecology, 87(2), 193-210.

Gleason, H. A. (1926). The individualistic concept of the plant association. Bulletin of the Torrey Botanical Club, 53(1), 7-26.

Gómez-Pompa, A., \& Vázquez-Yanes, C. (1981). Successional studies of a rain forest in Mexico. In D. C. West, H. H. Shugart, \& D. B. Botkin (Eds.), Forest Succession (pp. 246-266). New York: Springer.

Gommers, C. M., Visser, E. J., St Onge, K. R., Voesenek, L. A., \& Pierik, R. (2013). Shade tolerance: when growing tall is not an option. Trends in Plant Science, $18(2), 65-71$.

Gravel, D., Canham, C. D., Beaudet, M., \& Messier, C. (2010). Shade tolerance, canopy gaps and mechanisms of coexistence of forest trees. Oikos, 119(3), 475-484.

Greig, N. (1993). Regeneration mode in neotropical Piper: habitat and species comparisons. Ecology, 74(7), 2125-2135.

Grime, J. P. (1977). Evidence for the existence of three primary strategies in plants and its relevance to ecological and evolutionary theory. The American Naturalist, 111(982), 1169-1194.

Grime, J. P. (1989). Whole-plant responses to stress in natural and agricultural systems. In H. G. Jones, T. J. Flowers, \& M. B. Jones (Eds.), Plants under stress: biochemistry, physiology and ecology and their application to plant improvement (pp. 31-46). Cambridge: Cambridge University Press.

Grime, J. P. (2007). Plant strategy theories: a comment on Craine (2005). Journal of Ecology, 95(2), 227-230.

Guariguata, M. R., \& Ostertag, R. (2001). Neotropical secondary forest succession: changes in structural and functional characteristics. Forest Ecology and Management, 148(1-3), 185-206.

Hillebrand, H. (2004). On the generality of the latitudinal diversity gradient. The American Naturalist, 163(2), 192-211.

Hubbell, S. P. (1997). A unified theory of biogeography and relative species abundance and its application to tropical rain forests and coral reefs. Coral Reefs, 16(1), S9-S21.
Hubbell, S. P., Foster, R. B., O'Brien, S. T., Harms, K. E., Condit, R., Wechsler, B., ... \& De Lao, S. L. (1999). Light-gap disturbances, recruitment limitation, and tree diversity in a neotropical forest. Science, 283(5401), 554-557.

Hubbell, S. P. (2001). The unified neutral theory of biodiversity and biogeography. Princeton \& Oxford: Princeton University Press.

Huston, M. A. (1999). Local processes and regional patterns: appropriate scales for understanding variation in the diversity of plants and animals. Oikos, 86(3), 393-401.

Jansson, R., Rodríguez-Castañeda, G., \& Harding, L. E. (2013). What can multiple phylogenies say about the latitudinal diversity gradient? A new look at the tropical conservatism, out of the tropics, and diversification rate hypotheses. Evolution, 67(6), 1741-1755.

Janzen, D. H. (1970). Herbivores and the number of tree species in tropical forests. The American Naturalist, 104(940), 501-528.

Kitajima, K. (1994). Relative importance of photosynthetic traits and allocation patterns as correlates of seedling shade tolerance of 13 tropical trees. Oecologia, 98(34), 419-428.

Kitajima, K. (2002). Do shade-tolerant tropical tree seedlings depend longer on seed reserves? Functional growth analysis of three Bignoniaceae species. Functional Ecology, 16(4), 433-444.

Kitajima, K., Mulkey, S. S., \& Wright, S. J. (2004). Variation in crown light utilization characteristics among tropical canopy trees. Annals of Botany, 95(3), 535-547.

Kitajima, K., \& Poorter, L. (2008). Functional basis for resource niche partitioning by tropical trees. In W. P. Carson, \& S. A. Schnitzer (Eds.), Tropical Forest Community Ecology (pp. 172-188). Oxford: Blackwell.

Kitajima, K., \& Poorter, L. (2010). Tissue-level leaf toughness, but not lamina thickness, predicts sapling leaf lifespan and shade tolerance of tropical tree species. New Phytologist, 186(3), 708-721.

Kobe, R. K., \& Coates, K. D. (1997). Models of sapling mortality as a function of growth to characterize interspecific variation in shade tolerance of eight tree species of northwestern British Columbia. Canadian Journal of Forest Research, 27(2), 227-236.

Kozlowski, T. T., \& Pallardy, S. G. (2002). Acclimation and adaptive responses of woody plants to environmental stresses. The Botanical Review, 68(2), 270-334.

Kraft, N. J., Adler, P. B., Godoy, O., James, E. C., Fuller, S., \& Levine, J. M. (2015). Community assembly, 
coexistence and the environmental filtering metaphor. Functional Ecology, 29(5), 592-599.

Kraft, N. J., Valencia, R., \& Ackerly, D. D. (2008). Functional traits and niche-based tree community assembly in an Amazonian forest. Science, 322(5901), 580-582.

Kursar, T. A., \& Coley, P. D. (1992). Delayed greening in tropical leaves: an antiherbivore defense?. Biotropica, 24(2), 256-262.

Lebrija-Trejos, E., Pérez-García, E. A., Meave, J. A., Bongers, F., \& Poorter, L. (2010). Functional traits and environmental filtering drive community assembly in a species-rich tropical system. Ecology, 91(2), 386-398.

Lebrija-Trejos, E., Pérez-García, E. A., Meave, J. A., Poorter, L., \& Bongers, F. (2011). Environmental changes during secondary succession in a tropical dry forest in Mexico. Journal of Tropical Ecology, 27(5), 477-489.

Lee, D. W., Baskaran, K., Mansor, M., Mohamad, H., \& Yap, S. K. (1996). Irradiance and spectral quality affect Asian tropical rain forest tree seedling development. Ecology, 77(2), 568-580.

Letcher, S. G. (2010). Phylogenetic structure of angiosperm communities during tropical forest succession. Proceedings of the Royal Society of London B: Biological Sciences, 277(1678), 97-104.

Letcher, S. G., Chazdon, R. L., Andrade, A. C., Bongers, F., van Breugel, M., Finegan, B., ... \& Williamson, G. B. (2012). Phylogenetic community structure during succession: evidence from three Neotropical forest sites. Perspectives in Plant Ecology, Evolution and Systematics, 14(2), 79-87.

Letcher, S. G., Lasky, J. R., Chazdon, R. L., Norden, N., Wright, S. J., Meave, J. A., ... \& Andrade, J. L. (2015). Environmental gradients and the evolution of successional habitat specialization: a test case with 14 Neotropical forest sites. Journal of Ecology, 103(5), 1276-1290.

Lohbeck, M., Lebrija-Trejos, E., Martínez-Ramos, M., Meave, J. A., Poorter, L., \& Bongers, F. (2015). Functional trait strategies of trees in dry and wet tropical forests are similar but differ in their consequences for succession. PloS One, 10(4), e0123741.

MacArthur, R., \& Levins, R. (1964). Competition, habitat selection, and character displacement in a patchy environment. Proceedings of the National Academy of Sciences, 51(6), 1207-1210.

Markesteijn, L., Poorter, L., Bongers, F., Paz, H., \& Sack, L. (2011). Hydraulics and life history of tropical dry forest tree species: coordination of species' drought and shade tolerance. New Phytologist, 191(2), 480-495.
Martínez-Ramos, M., Alvarez-Buylla, E., \& Sarukhan, J. (1989). Tree demography and gap dynamics in a tropical rain forest. Ecology, 70(3), 555-558.

Martínez-Ramos, M., \& Soto-Castro, A. (1993). Seed rain and advanced regeneration in a tropical rain forest. Vegetatio, 107(1), 299-318.

McCarthy, M. C., \& Enquist, B. J. (2007). Consistency between an allometric approach and optimal partitioning theory in global patterns of plant biomass allocation. Functional Ecology, 21(4), 713-720.

McGill, B. J., Enquist, B. J., Weiher, E., \& Westoby, M. (2006). Rebuilding community ecology from functional traits. Trends in Ecology \& Evolution, 21(4), 178-185.

Meiners, S. J., Cadotte, M. W., Fridley, J. D., Pickett, S. T., \& Walker, L. R. (2015). Is successional research nearing its climax? New approaches for understanding dynamic communities. Functional Ecology, 29(2), 154-164.

Melo, F. P., Arroyo-Rodríguez, V., Fahrig, L., MartínezRamos, M., \& Tabarelli, M. (2013). On the hope for biodiversity-friendly tropical landscapes. Trends in Ecology \& Evolution, 28(8), 462-468.

Mesquita, R. D. C. G., Massoca, P. E. D. S., Jakovac, C. C., Bentos, T. V., \& Williamson, G. B. (2015). Amazon rain forest succession: stochasticity or land-use legacy? BioScience, 65(9), 849-861.

Mittelbach, G. G., Schemske, D. W., Cornell, H. V., Allen, A. P., Brown, J. M., Bush, M. B., ... \& McCain, C. M. (2007). Evolution and the latitudinal diversity gradient: speciation, extinction and biogeography. Ecology Letters, 10(4), 315-331.

Montgomery, R., \& Chazdon, R. J. (2002). Light gradient partitioning by tropical tree seedlings in the absence of canopy gaps. Oecologia, 131(2), 165-174.

Muscarella, R., Uriarte, M., Aide, T. M., Erickson, D. L., Forero-Montaña, J., Kress, W. J., ... \& Zimmerman, J. K. (2016). Functional convergence and phylogenetic divergence during secondary succession of subtropical wet forests in Puerto Rico. Journal of Vegetation Science, 27(2), 283-294.

Niinemets, Ü. (2006). The controversy over traits conferring shade-tolerance in trees: ontogenetic changes revisited. Journal of Ecology, 94(2), 464-470.

Niinemets, Ü. (2010a). A review of light interception in plant stands from leaf to canopy in different plant functional types and in species with varying shade tolerance. Ecological Research, 25(4), 693-714.

Niinemets, Ü. (2010b). Responses of forest trees to single and multiple environmental stresses from seedlings to mature plants: past stress history, stress interactions, 
tolerance and acclimation. Forest Ecology and Management, 260(10), 1623-1639.

Norden, N., Angarita, H. A., Bongers, F., Martínez-Ramos, M., Granzow-de la Cerda, I., Van Breugel, M., ... \& Finegan, B. (2015). Successional dynamics in Neotropical forests are as uncertain as they are predictable. Proceedings of the National Academy of Sciences, 112(26), 8013-8018.

Norden, N., Boukili, V., Chao, A., Ma, K. H., Letcher, S. G., \& Chazdon, R. L. (2017). Opposing mechanisms affect taxonomic convergence between tree assemblages during tropical forest succession. Ecology Letters, 20(11), 1448-1458L.

Novotny, V., Drozd, P., Miller, S. E., Kulfan, M., Janda, M., Basset, Y., \& Weiblen, G. D. (2006). Why are there so many species of herbivorous insects in tropical rain forests? Science, 313(5790), 1115-1118.

Oliver, C. D., \& Larson, B. C. (1996). Forest stand dynamics: updated edition. New Jersey: John Wiley.

Pacala, S. W., \& Rees, M. (1998). Models suggesting field experiments to test two hypotheses explaining successional diversity. The American Naturalist, 152(5), 729-737.

Peña-Claros, M., \& Zuidema, P. (2000). Demographic limitations for the sustainable extraction of palm heart from Euterpe precatoria in two forest types in Bolivia. Ecología en Bolivia, 34, 7-25.

Peterson, C. J., \& Carson, W. P. (2008). Processes constraining woody species succession on abandoned pastures in the tropics: on the relevance of temperate models of succession. In W. Carson, \& S. Schnitzer (Eds.), Tropical forest community ecology (pp. 367383). Oxford: Wiley-Blackwell.

Plourde, B. T., Boukili, V. K., \& Chazdon, R. L. (2015). Radial changes in wood specific gravity of tropical trees: inter-and intraspecific variation during secondary succession. Functional Ecology, 29(1), 111-120.

Poorter, L. (2007). Are species adapted to their regeneration niche, adult niche, or both? The American Naturalist, 169(4), 433-442.

Poorter, L. (2009). Leaf traits show different relationships with shade tolerance in moist versus dry tropical forests. New Phytologist, 181(4), 890-900.

Poorter, L., \& Arets, E. J. (2003). Light environment and tree strategies in a Bolivian tropical moist forest: an evaluation of the light partitioning hypothesis. Plant Ecology, 166(2), 295-306.

Poorter, L., Bongers, F., Sterck, F. J., \& Wöll, H. (2005). Beyond the regeneration phase: differentiation of height-light trajectories among tropical tree species. Journal of Ecology, 93(2), 256-267.
Poorter, L., \& Rose, S. A. (2005). Light-dependent changes in the relationship between seed mass and seedling traits: a meta-analysis for rain forest tree species. Oecologia, 142(3), 378-387.

Poorter, L., Wright, S. J., Paz, H., Ackerly, D. D., Condit, R., Ibarra-Manríquez, G., ... \& Muller-Landau, H. C. (2008). Are functional traits good predictors of demographic rates? Evidence from five neotropical forests. Ecology, 89(7), 1908-1920.

Prado, A., Sierra, A., Windsor, D., \& Bede, J. C. (2014). Leaf traits and herbivory levels in a tropical gymnosperm, Zamia stevensonii (Zamiaceae). American Journal of Botany, 101(3), 437-447.

Prescott, C. E. (2002). The influence of the forest canopy on nutrient cycling. Tree physiology, 22(15-16), 1193-1200.

Putz, F. E. (1984). The natural history of lianas on Barro Colorado Island, Panama. Ecology, 65(6), 1713-1724.

Rees, M., Condit, R., Crawley, M., Pacala, S., \& Tilman, D. (2001). Long-term studies of vegetation dynamics. Science, 293(5530), 650-655.

Reich, P. B. (2014). The world-wide 'fast-slow' plant economics spectrum: a traits manifesto. Journal of Ecology, 102(2), 275-301.

Reich, P. B., Wright, I. J., Cavender-Bares, J., Craine, J. M., Oleksyn, J., Westoby, M., \& Walters, M. B. (2003). The evolution of plant functional variation: traits, spectra, and strategies. International Journal of Plant Sciences, 164(S3), S143-S164.

Richards, P.W. (1952). The tropical rain forest: an ecological study. Cambridge: Cambridge University Press.

Rosindell, J., Hubbell, S. P., \& Etienne, R. S. (2011). The unified neutral theory of biodiversity and biogeography at age ten. Trends in Ecology \&Evolution, 26(7), 340-348.

Santiago, L. S., \& Wright, S. J. (2007). Leaf functional traits of tropical forest plants in relation to growth form. Functional Ecology, 21(1), 19-27.

Sapijanskas, J., Paquette, A., Potvin, C., Kunert, N., \& Loreau, M. (2014). Tropical tree diversity enhances light capture through crown plasticity and spatial and temporal niche differences. Ecology, 95(9), 2479-2492.

Schaetzl, R. J., Burns, S. F., Johnson, D. L., \& Small, T. W. (1988). Tree uprooting: review of impacts on forest ecology. Vegetatio, 79(3), 165-176.

Schaller, A. (2008). Induced plant resistance to herbivory. Berlin: Springer. 
Schlichting, C. D., \& Pigliucci, M. (1998). Phenotypic evolution: a reaction norm perspective. Sunderland: Sinauer.

Schnitzer, S. A., Mascaro, J., \& Carson, W. P. (2008). Treefall gaps and the maintenance of plant species diversity in tropical forests. In W. P. Carson, \& S. A. Schnitzer (Eds.), Tropical Forest Community Ecology (pp. 196-209). Oxford: Blackwell.

Schupp, E. W., Howe, H. F., Augspurger, C. K., \& Levey, D. J. (1989). Arrival and survival in tropical treefall gaps. Ecology, 70(3), 562-564.

Schwalm, C. R., Anderegg, W. R., Michalak, A. M., Fisher, J. B., Biondi, F., Koch, G., ... \& Huntzinger, D. N. (2017). Global patterns of drought recovery. Nature, 548(7666), 202.

Spasojevic, M. J., Yablon, E. A., Oberle, B., \& Myers, J. A. (2014). Ontogenetic trait variation influences tree community assembly across environmental gradients. Ecosphere, 5(10), 1-20.

Sterck, F., Markesteijn, L., Schieving, F., \& Poorter, L. (2011). Functional traits determine trade-offs and niches in a tropical forest community. Proceedings of the National Academy of Sciences, 108(51), 20627-20632.

Strauss-Deberiedetti, S., \& Bazzaz, F. A. (1996). Photosynthetic characteristics of tropical trees along successional gradients. In S. S. Mulkey, R. L. Chazdon, \& A. P. Smith (Eds.), Tropical forest plant ecophysio$\operatorname{logy}$ (pp. 162-186). Boston: Springer.

Swaine, M. D., \& Whitmore, T. C. (1988). On the definition of ecological species groups in tropical rain forests. Vegetatio, 75(1-2), 81-86.

Swenson, N. G., Stegen, J. C., Davies, S. J., Erickson, D. L., Forero-Montaña, J., Hurlbert, A. H., ... \& Zimmerman, J. K. (2012). Temporal turnover in the composition of tropical tree communities: functional determinism and phylogenetic stochasticity. Ecology, 93(3), 490-499.

Svenning, J. C. (1999). Microhabitat specialization in a species-rich palm community in Amazonian Ecuador. Journal of Ecology, 87(1), 55-65.

Sylvester, O., \& Avalos, G. (2013). Influence of light conditions on the allometry and growth of the understory palm Geonoma undata subsp. edulis (Arecaceae) of neotropical cloud forests. American Journal of Botany, 100(12), 2357-2363.

Tilman, D. (1977). Resource competition between plankton algae: an experimental and theoretical approach. Ecology, 58(2), 338-348.

Tilman, D. (1990). Constraints and tradeoffs: toward a predictive theory of competition and succession. Oikos, $58(1), 3-15$.
Tilman, D. (1994). Competition and biodiversity in spatially structured habitats. Ecology, 75(1), 2-16.

Tomlinson, P. B. (2006). The uniqueness of palms. Botanical Journal of the Linnean Society, 151(1), 5-14.

Urban, M. C., Leibold, M. A., Amarasekare, P., De Meester, L., Gomulkiewicz, R., Hochberg, M. E., ... \& Pantel, J. H. (2008). The evolutionary ecology of metacommunities. Trends in Ecology \& Evolution, 23(6), 311-317.

Valladares, F., \& Niinemets, Ü. (2008). Shade tolerance, a key plant feature of complex nature and consequences. Annual Review of Ecology, Evolution, and Systematics, 39, 237-257.

Valladares, F., Laanisto, L., Niinemets, Ü., \& Zavala, M. A. (2016). Shedding light on shade: ecological perspectives of understorey plant life. Plant Ecology \& Diversity, 9(3), 237-251.

Valladares, F., Sánchez-Gómez, D., \& Zavala, M. A. (2006). Quantitative estimation of phenotypic plasticity: bridging the gap between the evolutionary concept and its ecological applications. Journal of Ecology, 94(6), 1103-1116.

Vellend, M. (2010). Conceptual synthesis in community ecology. The Quarterly Review of Biology, 85(2), 183-206.

Violle, C., Navas, M. L., Vile, D., Kazakou, E., Fortunel, C., Hummel, I., \& Garnier, E. (2007). Let the concept of trait be functional! Oikos, 116(5), 882-892.

Way, D. A., \& Pearcy, R. W. (2012). Sunflecks in trees and forests: from photosynthetic physiology to global change biology. Tree Physiology, 32(9), 1066-1081.

Webb, C. O. (2000). Exploring the phylogenetic structure of ecological communities: an example for rain forest trees. The American Naturalist, 156(2), 145-155.

Webb, C. O., Ackerly, D. D., McPeek, M. A., \& Donoghue, M. J. (2002). Phylogenies and community ecology. Annual Review of Ecology and Systematics, 33(1), 475-505.

Webb, C. O., Cannon, C. H., \& Davies, S. J. (2008). Ecological organization, biogeography, and the phylogenetic structure of tropical forest tree communities. In W. P. Carson, \& S. A. Schnitzer (Eds.), Tropical Forest Community Ecology (pp. 79-97). New Jersey: Wiley-Blackwell.

Weiher, E., Freund, D., Bunton, T., Stefanski, A., Lee, T., \& S. Bentivenga. (2013). Advances, challenges and developing synthesis of ecological community assembly theory. Philosophical Transactions of the Royal Society B, 366, 2403-2413. 
Weiner, J. (2004). Allocation, plasticity and allometry in plants. Perspectives in Plant Ecology, Evolution and Systematics, 6(4), 207-215.

West-Eberhard, M. J. (2003). Developmental plasticity and evolution. Oxford: Oxford University Press.

Wright, J. S. (2002). Plant diversity in tropical forests: a review of mechanisms of species coexistence. Oecologia, 130(1), 1-14.

Wright, S. J., Kitajima, K., Kraft, N. J., Reich, P. B., Wright, I. J., Bunker, D. E., ... \& Engelbrecht, B. M. (2010). Functional traits and the growth-mortality trade-off in tropical trees. Ecology, 91(12), 3664-3674.

Wright, S. J., Muller-Landau, H. C., Condit, R., \& Hubbell, S. P. (2003). Gap-dependent recruitment, realized vital rates, and size distributions of tropical trees. Ecology, 84(12), 3174-3185.

Wright, I. J., Reich, P. B., Westoby, M., Ackerly, D. D., Baruch, Z., Bongers, F., ... \& Flexas, J. (2004). The worldwide leaf economics spectrum. Nature, 428(6985), 821.

Zimmerman, J. K., Thompson, J., \& Brokaw, N. (2008). Large tropical forest dynamics plots: testing explanations for the maintenance of species diversity. In W. Carson, \& S. Schnitzer (Eds.), Tropical forest community ecology (pp. 98-117). Oxford: Wiley-Blackwell.

Zotz, G., \& Hietz, P. (2001). The physiological ecology of vascular epiphytes: current knowledge, open questions. Journal of Experimental Botany, 52(364), 2067-2078 